\title{
Duration of activities and energy expenditure of female farmers in dry and rainy seasons in Upper-Volta
}

\author{
BY FANNY M. BLEIBERG, THIERRY A. BRUN AND S. GOIHMAN \\ Unité de Recherche en Nutrition, $U_{1}$, INSERM, Hôpital Bichat, I70 Bd Ney, 7875018 \\ Paris, France
}

\section{AND EMILE GOUBA}

\begin{abstract}
Cellule de Nutrition, Ministère de la Santé Publique et des Affaires Sociales, Ouagadougou, R. Haute-Volta
\end{abstract}

\section{(Received 18 July 1979 - Accepted 3 August 1979)}

\begin{abstract}
I. Fifteen female farmers (aged 18-47 years) from two villages of the Mossi Plateau in Upper-Volta participated in a survey in which their daily activity pattern and their energy expenditure were assessed. Eight of the subjects were investigated twice, in March (dry season) when there is no agricultural activity, and in July-August (rainy season) when heavy physical work is performed: mostly hoeing, weeding and replanting sorghum (Sorghum vulgare) and millet (Pennisetum typhoides).

2. The mean height was $1.57 \mathrm{~m}$ and the mean weight $50.6 \mathrm{~kg}$. The average percentage of body fat, calculated from skinfold thickness, was comparable to that of European females but the triceps skinfold was more than $60 \%$ below the standard value (Jelliffe, 1969). The type of activities and the period of time spent on each activity changed significantly with the season. The mean energy output rose from $9 \cdot 7 \mathrm{MJ}$ ( $2320 \mathrm{kcal})$ in March to $12.1 \mathrm{MJ}(2890 \mathrm{kcal})$ in July-August for a $55 \mathrm{~kg}$ standard weight.

3. In this paper, the extent of both the daily activity pattern of women living in a subsistence agriculture and their energy output is estimated. The results suggest that during the rainy season, the energy requirements of female farmers are much higher than usually estimated.
\end{abstract}

As do most of the women from African countries, female farmers from Upper-Volta play an important role in the economic activities of the country, particularly in the production and marketing of foodstuffs. This results in part from the migration of adult males to the cities and the coastal countries in search of paid employment. The growing involvement of male farmers in the production of cash crops: groundnut (Arachis hypogaea) and cotton (Gossypium spp.) mainly, has left in the hands of the women the responsibility to produce a large share of the food supply. Female farmers, in fact, provide not only cereals for home consumption but also part of the cereals consumed in the cities.

In the Sahel countries the adjustment of food supply to food requirements appears frequently out of equilibrium and rural women are exposed to undernutrition and sometimes severe food shortages (Annegers, 1973; Ancey, 1974; Brun \& Kovess, 1974; Bugnicourt, 1974; Comite Sahel, I974). Their health might affect the nutritional status of their children, particularly during pregnancy and lactation, and also their productivity. In view of their prominent role in the reproduction of the labour force and the production of foodstuffs, female farmers should be one of the major concerns of the food and nutrition planners. Whereas the tasks performed by women are frequently acknowledged, few studies have attempted to describe precisely their activities and measure their energy expenditure.

Ancey (1974) in Upper-Volta has recorded by recall on a one year basis, the duration of all the tasks of a large group of female farmers from five villages. However, he did not measure the energy cost of their activities. In Gambia, A. Paul, E. M. Müller \& R. G. Whitehead (personal communication) have assessed the period of time spent in various 
activities by lactating women, but did not estimate energy expenditure. From field measurements of oxygen consumption, Fox (1953) calculated the daily energy expenditure of Gambian farmers for periods of I month; the results, expressed per head, do not indicate the energy output of men and women separately.

In this study we have attempted to assess the daily rate of energy expenditure of female farmers from an accurate recording of the period of time spent in their home, in the villages, the market and their fields. This research was conducted at the peak of the rainy season under conditions of heavy farm work and during the dry season when the time is spent in miscellaneous activities of low energy cost.

\section{MATERIALS AND METHODS}

\section{Ecological setting}

Two villages are included in the study, both belong to the Mossi region in the centre of Upper-Volta. Nam-Ymi is located 25 miles South of Ouagadougou ( 3 miles east of Kombissiri). Dablo lies in a small valley, 35 miles west of Barsalogho. The mean annual rainfall in Nam-Ymi is $905 \mathrm{~mm}$ and in Dablo is $682 \mathrm{~mm}$. The mean annual temperature is approximately $28^{\circ}$ with an average minimum in January $\left(17^{\circ}\right)$ and a maximum mean of $39^{\circ}$ in April. Diurnal variations are high during the dry season $\left(15^{-20^{\circ}}\right)$ but lower during the rainy season.

The Mossi are sedentary farmers cultivating mostly millet (Pennisetum typhoides) and sorghum (Sorghum vulgare) and a few groundnuts (Arachis hypogaea), beans (Vigna unguiculata), peas (Voandzeia subterranea), sesame (Sesamum indicum), cotton (Gossypium spp.) and miscellaneous crops. They raise poultry, a small number of goats and sheep, and sometimes zebus, donkeys and horses.

The basic unit of production is the extended family. Families cultivate collective plots of land which provide the bulk of the supply for the household. In addition, women and various members of the family work in individual fields in which instance the harvest is used for their own need and in part to the benefit of the household. Division of labour is based on age and sex. Farming is performed by all members above the age of 7 years on the average. Women are in charge of all food-processing activities including searching for water and gathering wood. Old women and old men are usually exempted from communal farming but often help in looking after the children. Small livestock is often cared for by children who also protect the crops from the birds. The rainy season from May to November is dedicated almost entirely to agricultural activities. The threat of drought has been constant for decades and even in years of adequate rainfall some villages suffer from food shortage at the end of this rainy season, when agricultural work is heavy and grain reserves are depleted. The dry season is devoted to handicrafts and such trades as weaving, pottery and marketing of commercial foodstuffs such as doughnuts made of millet, sorghum, beans, and groundnuts.

\section{Subjects}

Twelve women were investigated at each season. Eight of them were studied in both periods; the others were selected in such a way as to obtain two groups of similar weight, height and activity. All the subjects had a comparable pattern of activities which included some agricultural work during the rainy season and the preparation of food during both periods of study. They can be considered as representative of the Mossi female farmers for all the factors described previously. 
Methods

Recording of period of time spent in 'everyday' activities and determination of energy expenditure.

Each woman was followed by an observer throughout the waking day for $48 \mathrm{~h}$. A diary was kept by the investigator who registered accurately the period of time spent in every activity and described each task and the position of the body.

The energy cost of resting and most typical activities was determined by indirect calorimetry (for approximately $10 \mathrm{~min}$ ) by means of a Kofranyi-Michaelis respirometer. Barometric pressure was read on an aneroid barometer. After the end of the measurement, expired air was analysed before $5 \mathrm{~min}$ elapsed, using a Servomex $\mathrm{O}_{2}$ analyser (AO 240) regularly calibrated with $99.9 \%$ nitrogen and ambient air.

The energy cost $(E)$ of the various activities was computed from the equation given by Durnin \& Passmore (1967) and based on Weir's (I949) formula

$$
E(\mathrm{kcal} / \mathrm{min})=\frac{4.92 \mathrm{~V}}{100}\left(20.93-\mathrm{O}_{22}\right)
$$

where $V$ is the volume of expired air reduced to standard temperature and pressure and corrected using the calibration constant of the meter, the value of which was verified, and $\mathrm{O}_{2 e}$ is the percentage of $\mathrm{O}_{2}$ in the expired air.

The $\mathrm{O}_{2}$ consumption for the activities which could not be measured was either obtained from the literature or estimated. In the latter instance, it was assessed from a list of known activities of increasing energy value. This grading system was established from measurements performed in Iran (unpublished results), Upper-Volta (the present study), Guatemala (Viteri et al. 1971), Nigeria (Phillips, 1954) and from a review of the literature (Durnin \& Passmore, 1955).

As Norgan et al. (1974) observed in field studies, it is often impractical to measure the rate of $\mathrm{O}_{2}$ consumption either during sleep or in the early morning. Various ingestigators have estimated the metabolic rate during sleep from standard tables (Fleisch, 195I) used to predict the basal metabolic rate (BMR). In view of the disagreement existing on the effects of high environmental temperature on the BMR, we decided to assess it from our own measurements of $\mathrm{O}_{2}$ consumption, by a $15 \%$ reduction of the value obtained for subjects lying inactive whatever was the time of the determination. However no determinations were made after the main meals but rather in the morning or late afternoon.

Daily energy expenditure was computed using the mean values for each activity, resulting from measurements performed on women belonging to the sample and other women living in the investigated villages. The energy cost of the activities measured on each subject has been calculated for a standard weight of $55 \mathrm{~kg}$.

The study was carried out in the dry season between 8 March and 2 April and in the rainy season between 30 July and 2 August.

\section{Anthropometric measurements}

Body-weight. The anthropometric measurements were all made by a single trained investigator. The subjects were weighed in their normal clothes on a beam balance in their courtyard or close to their hut. They were then asked to change clothes and bring what they were wearing to be weighed so as to calculate the nude weight of all subjects in both seasons.

Skinfold thicknesses and percentage body fat. The Harpenden skinfold caliper was used to measure the skinfolds at the biceps, triceps, sub-scapular and supra-iliac sites. All measurements were made on the left side of the body by the same investigator according to the 
recommendations given by Durnin \& Rahaman (1967). Body density was calculated using the regression equation for females published by Durnin \& Rahaman (1967). Siri's (1956) formula was adopted to assess the percentage of body fat.

Statistical analysis. Results are given as mean values \pm 1 standard error of the mean. They were analysed using the Student's $t$ test except comparisons between the durations of categories of activity during the dry and rainy seasons (Table 4) which were made using the distribution-free Mann and Whitney $U$ test.

\section{RESULTS}

\section{Anthropometric measurements}

The women involved in this study were aged 20-40 years (Table I). There was no significant difference between villages for any of the factors studied, except age. The subjects were significantly older in Nam-Ymi than in Dablo. No pregnant woman was included in Table I. The mean weight ( $5 \mathrm{I} \mathrm{kg}$ )-for-height $(1.57 \mathrm{~m}$ ) was $94 \%$ of the Inter-departmental Committee on Nutrition for National Development standard (Inter-departmental Committee on Nutrition for National Development, 1963). Body fat, calculated from the skinfold thickness, was approximately $20 \%$. For European women, the mean percentage of body fat is between $20-25 \%$ body-weight (Trémolières, 1973). In this respect the female farmers included in our survey seemed comparable to European subjects. Yet, the distribution of surface fat seemed to be very different in our sample since the thickness of the skinfold over the triceps did not reach $60 \%$ of the standard given by Jelliffe (I969). The distribution may be influenced by genetic factors and probably also by physical activities. Indeed, village women perform a large amount of domestic work with their arms throughout the year, in addition to the long hours of hoeing during the rainy season which also requires exhausting arm movements.

\section{Energy cost of the main activities}

The results for the energy cost of the various activities are shown in Table 2. Differences between the average energy expenditures for lying, sitting and standing were not significant.

Durnin \& Passmore (1967) present a grading system for women performing industrial work. By this system, all the measured activities would be classified as moderate (14.6-22.6 $\mathrm{kJ}(3.5-5.4 \mathrm{kcal})$ for a $55 \mathrm{~kg}$ woman) except washing clothes which falls in the category of light activities $(6 \cdot 3-14 \cdot 2 \mathrm{~kJ}(1 \cdot 5-3 \cdot 4 \mathrm{kcal}))$.

\section{Description of the main activities}

The period of time spent sitting included sitting in any situation and also light activities such as eating, chatting, breast-feeding, listening to the radio or reading.

The duration of each activity reported in Table 3 did not usually include the periods of rest within the activity. Rest periods were separated and included under the headings: lying, sitting and standing. An exception to this rule was made for visiting friends, social activities and visiting the market.

Looking after children consisted of washing, tending, feeding them and playing with them.

The women went to the market in order to purchase or to sell doughnuts and other foodstuffs or for both purposes; the periods of time spent walking to and from the market were totalled for all the subjects.

The usual meal consisted of sorghum or millet porridge, consumed with a sauce often prepared with leaves. In the rainy season, picking was therefore part of a meal preparation. A small quantity of wild fruits was also eaten during the day.

Food preparation included mainly hand-picking, pounding, grinding, winnowing and 
Table 1. Physical characteristics of female subjects in the dry season in Upper-Volta

(Mean values with their standard errors)

No. of women ...

Age (years)

Mean

SE

Height (m)

Mean

SE (NS)

Weight (kg)

Mean

SE (NS)

Skinfold (mm)

Biceps

Mean

SE (NS)

Triceps

Mean

SE (NS)

Sub-scapular

Mean

SE (NS)

Supra-iliac

Mean

SE

Fat $(\%)$

Mean

SE (NS)

\begin{tabular}{|c|c|c|}
\hline \multicolumn{2}{|c|}{ Village } & \multirow[b]{2}{*}{ Total } \\
\hline Nam-Ymi & Dablo & \\
\hline 8 & 7 & 15 \\
\hline $\begin{array}{c}37.9 \\
2.64\end{array}$ & $\begin{array}{l}22.3 \\
0.84^{* * *}\end{array}$ & $\begin{array}{c}30.6 \\
2.51\end{array}$ \\
\hline $\begin{array}{l}1.55 \\
0.018\end{array}$ & $\begin{array}{l}1.60 \\
0.029\end{array}$ & $\begin{array}{l}1.57 \\
0.017\end{array}$ \\
\hline $\begin{array}{c}47 \cdot 7 \\
1 \cdot 44\end{array}$ & $\begin{array}{r}54 \cdot 0 \\
3 \cdot 1\end{array}$ & $\begin{array}{c}50 \cdot 6 \\
1 \cdot 78\end{array}$ \\
\hline $\begin{array}{l}3 \cdot 3 \\
0 \cdot 30\end{array}$ & $\begin{array}{l}4 \cdot 1 \\
0 \cdot 43\end{array}$ & $\begin{array}{l}3 \cdot 6 \\
0.27\end{array}$ \\
\hline $\begin{array}{l}8.5 \\
1.06\end{array}$ & $\begin{array}{l}9.9 \\
1.80\end{array}$ & $\begin{array}{l}9 \cdot 2 \\
0.99\end{array}$ \\
\hline $\begin{array}{l}9 \cdot I \\
0 \cdot 78\end{array}$ & $\begin{array}{l}8.8 \\
1 . \infty 0\end{array}$ & $\begin{array}{l}9 \cdot 0 \\
0.60\end{array}$ \\
\hline $\begin{array}{l}6.1 \\
0.63\end{array}$ & $\begin{array}{l}7.5 \\
1.41\end{array}$ & $\begin{array}{l}6.7 \\
0.73\end{array}$ \\
\hline $\begin{array}{l}18 \cdot 8 \\
1.26\end{array}$ & $\begin{array}{c}20.0 \\
I .03\end{array}$ & $\begin{array}{c}19 \cdot 3 \\
1.12\end{array}$ \\
\hline
\end{tabular}

NS, not significant. $\quad * * * P<0.001$.

Table 2. Energy expenditure of female farmers in Upper-Volta for various activities (Mean values with their standard errors)

Lying

Sitting

Standing

Walking

Sowing

Thinning out and replanting

Hoeing

Grinding grain on a millstone

Pounding

Fetching water from the well

Fetching water from the swamp

Washing clothes

Stirring sorghum or millet porridge

\begin{tabular}{|c|c|c|c|c|}
\hline \multirow{3}{*}{$\begin{array}{l}\text { No. of } \\
\text { subjects }\end{array}$} & \multicolumn{4}{|c|}{ Energy cost ${ }^{*}$} \\
\hline & \multicolumn{2}{|c|}{$\mathrm{kJ} / \mathrm{min}$} & \multicolumn{2}{|c|}{$\mathrm{kcal} / \mathrm{min}$} \\
\hline & Mean & SE & Mean & $\mathbf{S E}$ \\
\hline 29 & $5 \cdot 19$ & 0.172 & 1.24 & 0.041 \\
\hline 27 & 5.40 & 0.188 & 1.29 & 0.045 \\
\hline 27 & 5.65 & 0.197 & $1 \cdot 35$ & 0.047 \\
\hline 18 & $12 \cdot 6$ & 0.55 & $3 \cdot 0$ & 0.13 \\
\hline 4 & 159 & $1 \cdot 58$ & $3 \cdot 9$ & 0.38 \\
\hline 5 & 149 & $1 \cdot 36$ & $3 \cdot 6$ & 0.32 \\
\hline II & $18 \cdot 1$ & 1.08 & $4 \cdot 3$ & 0.26 \\
\hline 24 & 17.4 & 0.74 & 4.2 & 0.18 \\
\hline 32 & 19.0 & 0.89 & 4.5 & 0.21 \\
\hline 21 & $17 \cdot 1$ & 0.52 & $4 \cdot 1$ & 0.13 \\
\hline 2 & $16 \cdot 2$ & 0.54 & 3.9 & 0.13 \\
\hline 3 & 13.5 & 1.66 & $3 \cdot 2$ & 0.40 \\
\hline 7 & 15.6 & $I \cdot 67$ & $3 \cdot 7$ & 0.40 \\
\hline
\end{tabular}

* Energy cost corresponding to a standard weight of $55 \mathrm{~kg}$. 
Table 3. Daily mean duration (min) of various types of activities of female farmers in dry and rainy season in Upper-Volta

\begin{tabular}{|c|c|c|c|c|}
\hline \multirow[b]{2}{*}{ Type of activities } & \multicolumn{2}{|c|}{ Dry season } & \multicolumn{2}{|c|}{ Rainy season } \\
\hline & $\begin{array}{l}\text { No. of women } \\
\text { involved }\end{array}$ & $\begin{array}{c}\text { Mean } \\
\text { duration* }\end{array}$ & $\begin{array}{l}\text { No. of women } \\
\text { involved }\end{array}$ & $\underset{\text { duration }}{\text { Mean }}$ \\
\hline Sleepjng & 12 & $548 \cdot 9$ & 12 & $513 \cdot 0$ \\
\hline Lying & 7 & 20.9 & 10 & $37 \cdot 9$ \\
\hline Sitting & 12 & $188 \cdot 3$ & 12 & $228 \cdot 3$ \\
\hline Standing & I 2 & $71 \cdot 3$ & I 2 & $56 \cdot 3$ \\
\hline Walking & 12 & $51 \cdot 7$ & 12 & $30 \cdot 2$ \\
\hline Washing and dressing & II & $8 \cdot 4$ & 6 & $3 \cdot 3$ \\
\hline Tending children & 6 & $7 \cdot 7$ & 3 & $1 \cdot 3$ \\
\hline Visiting friends, health centre and social activities & 4 & $8 \cdot 3$ & 2 & $9 \cdot 0$ \\
\hline At the market & 5 & & 5 & \\
\hline Walking to and from & 5 & $9 \cdot 0$ & 5 & $20 \cdot 9$ \\
\hline Purchasing and loitering & 3 & $8 \cdot 9$ & 2 & 15.8 \\
\hline Selling & 3 & $33 \cdot 4$ & 3 & $28 \cdot 6$ \\
\hline Miscellaneous commercial activities & 2 & 1.6 & - & - \\
\hline Housework & 12 & & 12 & \\
\hline Preparing food & 12 & $84 \cdot 0$ & 12 & $60 \cdot 6$ \\
\hline Cooking meals & II & $67 \cdot 1$ & 12 & $60 \cdot 1$ \\
\hline Fetching water & 12 & $30 \cdot 4$ & II & $33 \cdot 5$ \\
\hline Gathering wood & 7 & 18.0 & 6 & 8.4 \\
\hline Picking wild leaves and foods & 2 & 1.6 & 6 & 13.8 \\
\hline Preparing food for sale & 3 & $76 \cdot 5$ & 2 & $23 \cdot 7$ \\
\hline Housekeeping & 7 & $25 \cdot 1$ & 5 & $2 \cdot 7$ \\
\hline Washing clothes & 5 & $9 \cdot 7$ & 5 & $20 \cdot 3$ \\
\hline Handicrafts & 10 & & $\mathbf{l}$ & \\
\hline Cotton handicrafts & 9 & 134.5 & - & - \\
\hline Other handicrafts & 4 & $36 \cdot 3$ & $\mathbf{I}$ & 0.2 \\
\hline Farming & - & - & 12 & - \\
\hline Walking to and from the fields & - & - & 12 & $50 \cdot 4$ \\
\hline Hoeing & - & - & II & $182 \cdot 4$ \\
\hline Thinning out and replanting & - & - & 4 & $34 \cdot 3$ \\
\hline Sowing & - & - & 2 & $4 \cdot 6$ \\
\hline Sheep, goat and poultry breeding & 4 & 0.4 & 2 & 1.5 \\
\hline
\end{tabular}

* The mean duration is computed from the total amount of time spent by the subjects for each activity, irrespective of the number of women who were actually involved.

washing cereal and leguminous plants. All these activities were performed at home and the short walks they required were included under the heading: walking, irrespective of the load carried or the purpose of the walk.

Cooking a meal meant lighting and keeping the fire burning, putting ingredients and foodstuffs in the pot, watching until they boiled and constantly stirring the porridge. It also included washing the dishes, filling the calabashes and bringing them to the members of the family.

The period of time devoted to handicrafts $(78 \%)$ was spent in ginning and spinning cotton. The remaining included various activities such as sewing and polishing the calabash, making soap, sewing clothes and mending a roof or a wall.

Stock breeding included tending animals, collecting termites to feed the poultry, locking up and talking out the cattle and keeping the goats out of the cultivated areas.

During sowing, the body was bent, the woman holding a small calabash filled with seeds. 
She dug a small hole with a pickaxe and dropped the seed. She covered it with earth and moved forwards.

The implement used for hoeing was a heart-shaped concave steel blade and fitted through the top of this, at an acute angle to the blade was a wooden handle, some $660 \mathrm{~mm}$ in length. She stood, the body bent, with legs apart, pulling the earth up towards her to get rid of weeds.

Thinning out and replanting can be described as pulling out of the soil part of the sorghum or millet shoots, to plant them in another part of the field, by means of a hoe.

\section{Pattern of activities in dry and rainy seasons}

There were obvious differences between the occupations of women during the two seasons (Table 4, Fig. I). On the average, during the dry season, they dedicated $2 \mathrm{~h}$ daily to cotton handicrafts and $0.5 \mathrm{~h}$ to other types of handicrafts (Table 3). By contrast the latter activities were almost non-existent during the rainy season when each day the women spent $3 \mathrm{~h}$ hoeing, $0.5 \mathrm{~h}$ thinning out and replanting millet or sorghum and approximately $\mathrm{I} \mathrm{h}$ walking to and from the fields.

As far as all the other activities were concerned the distribution-free Mann and Whitney $\mathrm{U}$ test indicated no significant difference in the duration of any of the everyday activities. However, the pattern of occupation seemed to be appreciably different for the two seasons. The length of time spent in the daily tasks appeared to be related to some climatic factors despite the absence of formal statistical confirmation of our observations.

With respect to housework for example, more time was spent in preparing and cooking meals during the dry season. This is particularly true for the preparation of foodstuffs for sale. Altogether, there was a difference of approximately $\mathrm{I} \cdot 5 \mathrm{~h}$ between the two seasons. This might also explain why women spent twice as much time gathering wood during the dry season.

When the rainy season came, food preparation was reduced to one hot meal per $d$ as most women were working in the fields at 12.00 hours. Breakfast was usually made of the scraps of the previous dinner, generally cold porridge and sauce. At that period, women had no time for housekeeping but they spent twice as much time washing as clothes got dirty more rapidly when working in the fields and walking in the mud. It was also possible that washing clothes was reduced during the dry season because of the lack of water in some of the wells observed in both Dablo and Nam-Ymi.

Picking was practised almost exclusively in the rainy season when wild leaves and fruits were available. During the dry season, the housewives used dried leaves gathered during the previous wet season and only collected leaves from the baobab tree (Adansonia digitata).

The values for some activities might be misleading and deserve some comments. Walking for instance was divided during the rainy season between walking to and from the fields and moving about for other purposes.

Obviously this did not apply to the dry season when no agricultural work was performed. The duration of resting, either lying, sitting or standing was similar at both periods. However the daily pattern of rest was quite different. During the period of heavy physical work in the fields, $23 \%$ of the daily period of sitting and $27 \%$ of the standing period corresponded to the addition of the short periods of rest while the women recovered at intervals from their exhausting hoeing activity. By contrast, sitting and standing in the dry season corresponded to periods of inactivity or leisure. Although the difference was not statistically significant, as indicated previously, the duration of sleeping seemed longer by $0.5 \mathrm{~h}$ during the dry season. 
Table 4. Statistical differences in duration of categories of activity (min) of female farmers between dry and rainy seasons in Upper-Volta

(Mean values with their standard errors calculated for twelve women in each season)

Categories of activity

I Rest (sleeping, lying, sitting, standing)

2 Housework (food preparation for sale and home consumption, housekeeping and washing clothes)

3 Handicrafts (cotton and other handicrafts)

4 Farming (walking to and from the fields and agricultural activities
Statistical significance of Rainy season difference between means Mean SE

$\overbrace{\text { Mean }}^{\text {Dry season }} \underbrace{}_{\text {SE }}$

825.5

$39 \cdot 64$

NS

$829 \cdot 1$

$24 \cdot 57$

$318 \cdot 0$

50.48

NS

$219 \cdot 8$

29.88

$169 \cdot 1$

$44 \cdot 27$

$P<0.002$

$P<0.002$

$27 \cdot 7$

$39 \cdot 59$
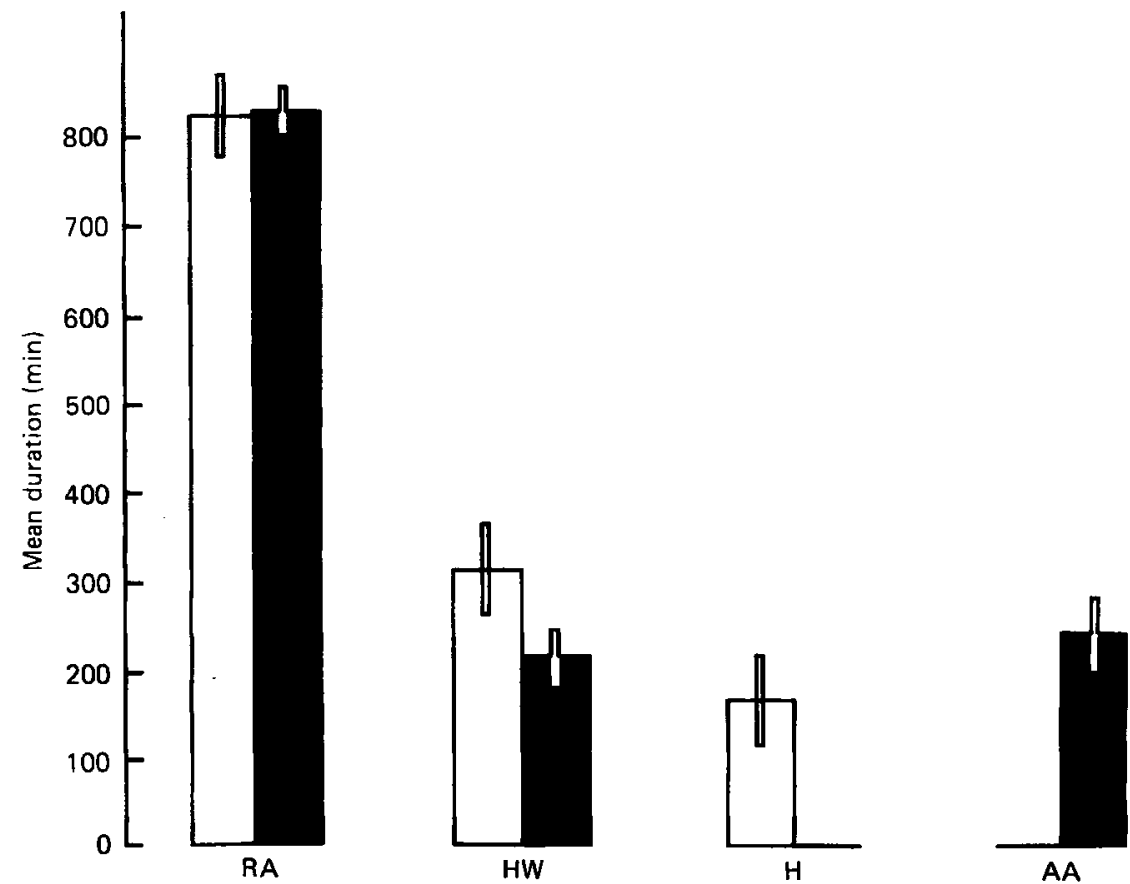

Fig. I. Duration (min) of various categories of activity: resting activities (RA), homework (HW), handicrafts $(\mathrm{H})$ and agricultural activities (AA) in dry $(\square)$ and rainy $(\mathbb{D})$ seasons. Standard errors are represented by vertical bars.

Daily energy output

According to the grading system given by FAO-WHO (1973), in the dry season, the female farmers are classified between moderately and very active with a mean energy cost of 0.18 $\mathrm{MJ} / \mathrm{kg}$ body-weight $(\mathbf{4 2 \cdot 2} \mathrm{kcal})$ and in the rainy season their energy output corresponds to 
exceptionally active subjects ( $0.22 \mathrm{MJ}$ or $52.6 \mathrm{kcal} / \mathrm{kg}$ body-weight). The range of values is wider in the rainy season ( $10.2-15.1 \mathrm{MJ}$ or $245 \mathrm{I}-36 \mathrm{IO} \mathrm{kcal}$ ) whereas in the dry season, the daily energy expenditure values are more homogeneous (8.7-11.2 MJ or 2070-2690 kcal) (Table 5).

\section{DISCUSSION}

There are numerous sources of inaccuracy in assessing daily energy expenditure and attempting to represent the average of a group at a certain period of the year. These series of errors have been studied by Durnin \& Brockway (1959). For instance the frequent error in recording the duration of each activity was considerably reduced by having these various activities observed and timed exactly by recruited observers from the same ethnic group.

Although this record was associated with a precise description of each task, there was always the possibility that some activities were performed with a higher intensity when measured than they would be on a normal working day. We were not sure, for example, that the women walked at the same pace or hoed at the same rate when wearing the meter as compared to their normal pattern. It is usually considered that subjects tend to increase rather than to reduce the intensity of their activities when observed or measured (Spurr et al. 1975). This might therefore lead to an over estimation of their metabolic rate. In comparing the approximate frequency and duration of short periods of rest during the most strenuous tasks, when measured or when only observed, we felt that there were no obvious differences. However, we had no way of assessing the possible errors due to the presence of an observer.

Over and above the sources of error reviewed by Durnin \& Brockway (1959) there is the possibility that the days on which the duration of the activity was recorded do not represent accurately the average pattern of activity for this period. This risk of error was particularly high during the wet season. The distribution of the rains was very erratic; since the amount of rain per month was rather small, the probability was high, on a few days of time-motion study, that we either underestimate or over estimate the duration of hoeing for example, which is closely tied to the moisture of the soil after the rain.

Fortunately, we were able to compare our short-term record of daily activity to another study conducted in Upper-Volta for one complete year on a much larger sample. From the observations of approximately $10000 \mathrm{~d}$ of 300 rural women over a I2-month period, Ancey (1974) computed the daily average duration of each type of activity per month. Using the energy cost of activities we have measured, we calculated the daily metabolic rate of Ancey's (1974) subjects for the same periods as our female farmers: March and July-August. Although there were some differences in the nature and duration of individual activities between the two surveys, the levels of energy expenditure at the two seasons are in close agreement (Table 6). The monthly level of energy expenditure, computed from Ancey's (1974) recording of activity, showed a gradual increase from $9.1 \mathrm{MJ}(2180 \mathrm{kcal}) / \mathrm{d}$ in January to $10.2 \mathrm{MJ}$ $(2430 \mathrm{kcal}) / \mathrm{d}$ in April. Our results approximated therefore to the mean energy output $(10.0 \mathrm{MJ}(2400 \mathrm{kcal}))$ for the whole dry season. Similarly, during the rainy season, the energy expenditure, computed from Ancey's (1974) survey, increased from I1.8 MJ (2810 kcal) in June to $11.5 \mathrm{MJ}(3000 \mathrm{kcal})$ in July and decreased to $12.1 \mathrm{MJ}(2890 \mathrm{kcal})$ in August. Our results were therefore close to the peak of energy output (12.3 MJ (2940 kcal)) of the rainy season.

In 1973, the year during which Ancey recorded the activities, rainfall was $28 \%$ below the average standard rainfall for this area but the number of days of rain was only $9 \%$ below normal. These values are computed from the tables of Agence pour la Sécurité de la Navigation Aérienne en Afrique et à Madagascar. Therefore, we cannot be certain that the level 
Table 5. Daily energy expenditure $\nmid$ of female farmers in dry and rainy seasons in Upper-Volta

(Mean values with their standard errors calculated for twelve women in each season)

\begin{tabular}{|c|c|c|c|c|}
\hline & \multicolumn{2}{|c|}{ MJ } & \multicolumn{2}{|c|}{ Kcal } \\
\hline & Mean & SE & Mean & SE \\
\hline Dry season & $9 \cdot 7$ & 0.23 & 2320 & $54 \cdot 8^{* * *}$ \\
\hline Rainy season & I $2 \cdot I$ & 0.47 & 2890 & I I I.9 \\
\hline
\end{tabular}

† Corresponding to a standard weight of $55 \mathrm{~kg}$.

*** $P<0.001$.

Table 6. Mean daily encrgy expenditure of female farmers in Upper-Volta computed from recordings of activity during 1973 (Ancey, 1974)

\begin{tabular}{|c|c|c|}
\hline \multirow[b]{2}{*}{ Month } & \multicolumn{2}{|c|}{ Energy expenditure } \\
\hline & MJ & Kcal \\
\hline January & 9. I & 2180 \\
\hline February & $9 \cdot 3$ & 2230 \\
\hline March & $9 \cdot 5$ & 2280 \\
\hline April & $10 \cdot 2$ & 2430 \\
\hline June & $11 \cdot 8$ & 2810 \\
\hline July & 12.5 & 3000 \\
\hline August & I 2. I & 2890 \\
\hline
\end{tabular}

of activity recorded during his study reflects the average level corresponding to this area. If not, it is rather an underestimation than an overestimation.

The energy expenditure while lying was not determined under standardized conditions and the period of time separating the measurement from the previous meal was not the same for all the subjects. Therefore, our values (Table 2) are higher than those published by Durnin \& Passmore (1967) for European women of the same weight and the same percentage of body fat just before rising $(3.8 \mathrm{~kJ}$ or $0.9 \mathrm{I} \mathrm{kcal} / \mathrm{min})$.

Surprisingly some subjects expended more energy while lying than while standing. Similar findings for sitting and standing have been reported by Durnin \& Namyslowski (1958) who emphasized the importance of individual variations. On average, the women involved in our study required slightly more energy while sitting than the women studied by Durnin \& Passmore (1967). However our results fall within the range of values given by Durnin \& Passmore (1967). The comparison between the metabolic rate of standing in the two populations showed no difference.

The energy cost of hoeing agrees with the measurements reported by Fox (1953) in Gambia.

Apprehension and nervousness during the measurements might also be responsible for the relatively high resting rate of energy expenditure of our subjects and might have led to an overestimation of the energy output during sleep. However, our values derived by $15 \%$ reduction of the values of lying are comparable to the calculated BMR of Aub \& Dubois (1917). This estimate for the metabolic rate for sleep was therefore of small significance as a source of error in the calculation of total daily energy expenditure. The activities estimated from the literature and from observations represented respectively $37 \%$ of the total amount of energy spent daily in the dry season and $13 \%$ in the rainy season. All heavy physical tasks were measured and in view of the small percentage of estimated values in July-August, we are reasonably convinced that the high energy output of the female farmers 
during the agricultural season reported, approximated to their true energy expenditure. In the dry season, there were more sources of error due to the higher number of estimations. Nevertheless, since all activities were light or moderate, the estimated values were probably of small significance as sources of error.

So far, there has been no accurate assessment of the energy expenditure of representative groups of West African peasants. It is difficult therefore to compare our findings with the results from other surveys. The average duration of the agricultural activities of the rainy season recorded in this study, is in close agreement with Fox's (1953) results from Gambian rural women: an average of $4 \mathrm{~h}$ was spent daily in these activities and the energy cost of hoeing measured in both surveys was similar. In Nigeria, Dema (1967) reported a mean daily energy expenditure of $13 . \mathrm{I} \mathrm{MJ}(3130 \mathrm{kcal})$ for women of slightly heavier weight than our subjects.

In practice, the energy output is measured chiefly for comparative purposes, either to estimate the gap between energy intake and expenditure, or to relate this difference to variations of body-weight or of other anthropometric measurements. Several investigators have reported low energy intakes among female African farmers (Ghana National Food and Nutrition Board 1961; Thomson et al. 1966) and weight loss during the rainy season (Thomson et al. 1966; Hunter 1967; Whitehead et al. 1978). M. Gentilini \& A. Froment (personal communication) have measured accurately an average weight loss of $2 \cdot 2 \mathrm{~kg}$ and a reduction of $7 \%$ of the triceps skinfold thickness between April and September 1977 , among seventeen female farmers in Upper-Volta.

Although we do not have firm evidence of a large-scale reduction of body-weight among farmers in Upper-Volta (F. M. Bleiberg, unpublished results showed a small but significant decrease in body-weight (approximately $650 \mathrm{~g}$ ) in twenty-two female subjects investigated in both seasons and no change in the percentage of body fat), comparison of the small amount of available information from various West African countries (Whitehead et al. 1978; Annegers, 1973), suggests that the energy output of the adults during the wet season is frequently above their energy intake.

Our study indicates that one of the reasons for the negative energy balance of some of the female agriculturalists, is the compulsion to spend long hours in heavy work in the fields during the rainy season.

In the type of subsistence agriculture prevailing in Upper-Volta, peasants have no source of power beyond that of their own muscles, since animal energy is scarcely used.

The authors are very grateful to M. Robert Poivre, Miss Catherine Layrac, Dr Françoise Bresh, Miss Sylvie Bonny, M. Idrissa Ouedraogo, Salif Ilboudo, for their technical assistance. The work described in this paper could not have been undertaken without the generous help of Professor Marc Gentilini and his research team. The authors would like also to thank the non-profit organization Frères des Hommes for its hospitality and its vehicles. This investigation was supported by several grants to Dr Thierry Brun from the Délégation Générale à la Recherche Scientifique et Technique (Nb 757 I 259/76 $70847 / 787008$ I-7 2249).

\section{REFERENCES}

Ancey, G. (1974). Facteurs et Systèmes de Production Dans La Société Mossi d'Augourd'hui. MigrationTravail - Terre et Capital. O.R.S.T.O.M.: Centre de Ouagadougou.

Annegers, J. F. (1973). Ecol. Fd Nutr. 2, 251.

Aub, J. C. \& Dubois, E. F. (1917). Archs intern. Med. 19, 823.

Brun, T. \& Kovess, V. (1974). Cah. Nutr. Diét. 9, I 19.

Bugnicourt, J. (1974). Un Peuple Privé de Son Environnement. Programme 'Formation pour l'environnement', Dakar: Institut Africain de developpement Economique et de Planification - United Nations Environment Program - Swedish International Development Agency. 
Comité Sahel (1974). Qui se Nourrit de La Famine en Afrique? Paris: Maspéro.

Copans, J. (1975). Sécheresses et Famines du Sahel. Paris: Maspéro.

Dema, D. S. (1967). 9 th A. Conf. Sci. Ass. Nigeria, University of Lagos.

Durnin, J. V. G. A. \& Brockway, J. M. (1959). Br. J. Nutr. 13, 41.

Durnin, J. V. G. A. \& Namyslowski, L. (1958). J. Physiol., Lond. 143, 573.

Durnin, J. V. G. A. \& Passmore, R. (1955). Physiol. Rev. 35, 80I.

Durnin, J. V. G. A. \& Passmore, R. (1967). Energy, Work and Leisure. London: Heinemann.

Durnin, J. V. G. A. \& Rahaman, M. M. (1967). Br. J. Nutr. 21, 681.

FAO/WHO. (1973). Tech. Rep. Ser. Wld Hlth Org. no. 522.

Fleisch, A. (1951). Helvet. med. Acta 18, 23.

Fox, R. H. (1953). Energy expenditure of Africans engaged in various rural activities. PhD Thesis, University of London.

Ghana National Food and Nutrition Board (1961). National Nutrition Survey. IV. The Nutrition of Adults in the North. Accra: Ghana National Food and Nutrition Board.

Hunter, J. M. (1967). Inst. Br. Geogr. Trans. Papers 41, 167.

Inter-departmental Committee on Nutrition for National Development (1963). Manual for Nutrition Surveys. Washington, DC: US Government Printing Office.

Jelliffe, D. B. (1969). Appréciation de l'état nutritionnel des populations. Séries de monographies no. 53, Genève: Org. mond. Santé.

Norgan, N. G., Ferro-Luzzi, A. \& Durnin, J. V. G. A. (1974). Phil. Trans. R. Soc. Lond. B 208, 309.

Phillips, P. G. (1954). J. trop. Med. Hyg. $57,12$.

Seamans, J., Holt, J., Rivers, J. \& Murlis, J. (1973). Lancet ii, 774.

Sheets, H. \& Morris, R. (1974). Disaster in the Desert. Failure of International Relief in the West African Drought. Special report. Washington, DC: The Carnegie Endowment for International Peace.

Siri, N. E. (1956). In Advances in Biological and Medical Physics [J. H. Lawrence and C. A. Tobias, editors]. London and New York: Academic Press.

Spurr, G. B., Barac-Nieto, M. \& Maksud, M. G. (1975). J. appl. Physiol. 39, 990.

Thomson, A. M., Billewicz, W. Z., Thompson, B. \& McGregor, I. A. (1966). J. Obstet. Gynaec. Br. Commonw. 73, 724 .

Trémolières, J. (1973). Nutrition, Physiologie, Comportement Alimentaire. Paris: Dunod.

Viteri, F. E., Torun, B., Galicia, J. C. \& Herrera, E. (1971). Am. J. clin. Nutr. 24, 418.

Weir, J. B. de V. (1949). J. Physiol., Lond. 109, I.

Whitehead, R. G., Rowland, M. G. M., Hutton, M., Prentice, A. M., Müller, E. \& Paul, A. (1978). Lancet ii, 178. 